\title{
PEANUT CROP PRODUCTIVITY IN A NEWLY RECLAIMED SALINE SOIL OF SAHL EL- TINA UNDER THE EFFECT OF USING NITROGEN MINERAL, ORGANIC AND BIO - FERTILIZERS
}

Ashmawy, Samia H.; Awatef A. Mahmoud and Dalia A. Saide Soils, Water and Environ. Res. Inst., Agric. Res. Center (ARC), Giza, Egtyp.

\begin{abstract}
A field experiment was conducted during the two successive seasons of 2007 and 2008 on a saline sandy clay soil at a private farm (Gelbana village), Sahl ElTina east Suez Canal. The aim was to study the effect of biofertilizer (a salt tolerant Bradyrhizobium sp.) humic acid and organic compost $\left(10 \mathrm{~m}^{3} \mathrm{fed}^{-1}\right)$ applied under two $\mathrm{N}$ rates, i.e. 25 and $50 \mathrm{~kg} \mathrm{~N}$ fed $^{-1}$ (as urea $46 \% \mathrm{~N}$ ) on peanut production and soil fertility under surface irrigation system.

The obtained results indicated that the use of biofertilizer, humic acid and compost combined with either 25 or $50 \mathrm{~kg} \mathrm{~N} \mathrm{fed}^{-1}$ led to significant increases in peanut straw, pod and seed yields as well as seed protein contents compared with mineral $\mathrm{N}$ fertilizer alone with slight difference between the two $\mathrm{N}$ rates, and compost treatment out yielded the other treatments. Application of the used materials also improved N, P and $\mathrm{K}$ uptake by straw and seeds as well as their contents of $\mathrm{Fe}, \mathrm{Mn}, \mathrm{Zn}$ and $\mathrm{Cu}$. Soil contents of the available macro-and micronutrients remained after peanut harvest were greatly ameliorated by the applied materials which seem to be quite useful for improving peanut yield and its quality as well as soil fertility under saline soil condition. The beneficial effects of the applied materials could categorize as: compost $>$ humic acid $>$ biofertilizer under the lower $\mathrm{N}$ rate.
\end{abstract}

\section{INTRODUCTION}

It is strongly believed that land reclamation and cultivation is principal may to salve food problems in Egypt. Leaching water is the principal limiting factor for reclaiming saline soils which are characterized by the highest salt concentration leading to low productivity for these soils.

Organic manure addition to these soils is also an important factor for facilitating chemical reclaiming processes through improving the structure and nutritional status.

Temperate climates depend on the water retaining properties of soils, and the properties of humic substances which are directly affected the environment and human health. The maximum values of organic matter content available nitrogen and available phosphorus were resulted by applying compost alone or mixed with biofertilizers to sandy soil (El-Sedfy et al., 2005). Genaidy and Hegazy (1991) found better rice yields in saline-sodic soils as a result of adding organic manure in the presence of gypsum application. Rajinder and Mandeep (2007) reported that continuous application of organic manures alone or in combination with $\mathrm{N}$ and $\mathrm{P}$ fertilizers for 10 years decreased the $\mathrm{pH}$ and increased the available $\mathrm{N}, \mathrm{P}$ and $\mathrm{K}$ as well as DTPA extractable $\mathrm{Zn}, \mathrm{Fe}, \mathrm{Mn}$ and $\mathrm{Cu}$ contents of soil. Abas 
(2003) found that high values of available $\mathrm{Fe}, \mathrm{Zn}, \mathrm{Mn}$ and $\mathrm{Cu}$ in sandy soil were obtained with applying organic and bio-organic fertilizers to sandy soil. Bhattacharyya et al. (2008) stated that the application of FYM resulted in increases in available $\mathrm{N}, \mathrm{P}$ and $\mathrm{K}$ in the soils, as FYM increased soil cation exchange capacity. Shaban et al. (2008) found that application of biofertilizer and organic fertilizers and their combination treatments increased slightly available $\mathrm{Fe}, \mathrm{Mn}, \mathrm{Zn}$ and $\mathrm{Cu}$ concentrations in the soil as compared to ammonium sulfate at the rate of $238 \mathrm{~kg} \mathrm{~N} \mathrm{ha}^{-1}$ as a sole treatment.

On the other hand, Wang et al. (1995) reported that the addition of humic acid to soil combined with $P$ fertilizer increased significantly the amount of water soluble phosphate and increased $\mathrm{P}$ uptake and yield by $25 \%$. Bama and Selvakumari (2001) found that application of $10 \mathrm{~kg}$ humic acid ha ${ }^{-1}$ as potassium humate along with $75 \%$ of the recommended dose of nitrogen fertilizer increased the crude protein content and mineral nutrition (P,K,Ca,Mg,Zn,Cu,Fe and Mn)of amaranths. El-Ghozoli (1998) reported that humic acid plays a very important role in element mobilization, availability of some nutrients and chelation of some heavy metals from soil and adsorbed on the mineral surfaces by functional groups.

Peanut (Arachis hypogaea $\mathrm{L}$ ) is considered one of the most important legume and oil seed crops, which cultivated and thrive in the newly reclaimed sandy soil in Egypt (Rashid and Ryan, 2004). Nasef et al. (2006) found that the inoculation with bio-fertilizer (Rhizobium strains) alone increased significantly the uptake of $\mathrm{N}, \mathrm{P}, \mathrm{K}, \mathrm{Fe}, \mathrm{Mn}, \mathrm{Zn}$ and $\mathrm{B}$ by straw and seeds of peanut as compared with the corresponding treatments without biofertilizer. El-Fayoumy and Ramadan (2002) reported that the number of pods per plant, 100 -seed weight and dry matter production of inoculated plants supplied with organic matter and mineral $\mathrm{N}$ showed positive and significant differences over inoculated unfertilized plants. Application of $\mathrm{OM}, \mathrm{N}$ and inoculation did not affect oil seed percentage, while seed protein content was quite affected.

This work aims to study the effect of using compost, humic acid and Rhizobia inoculation under $\mathrm{N}$ levels on the productivity of peanut crop cultivated in a newly reclaimed saline soil.

\section{MATERIALS AND METHODS}

Two field experiments were carried out at Sahl El-Tina in a private farm at Gelbana village, East Seuz Canal, Egypt, during the two successive summer seasons of 2007 and 2008 to study the effect of using organic fertilizers (compost and humic acid) and inoculation with Bray rhizobium sp under two $\mathrm{N}$ levels ( 25 and $50 \mathrm{~kg} \mathrm{~N}$ fed $^{-1}$ ) on the productivity of peanut crop cultivated in a newly reclaimed saline soil. The initial soil physical and chemical analyses according to Black 1965 and Page (1982) are presented in Table (1). The analysis of compost (Brunner and Wasmer, 1978) is shown in Table (2).

Prior to sowing, peanut seeds were coated with salt tolerant rhizobia inoculum $\left(750 \mathrm{~g} \mathrm{fed}^{-1}\right)$ or humic acid $\left(1 \mathrm{~g} \mathrm{seed}^{-1}\right)$ using Arabic gum as an adhesive agent; besides, after 21, 45 and 62 days from sowing, rhizobia 
solution $\left(5 \mathrm{~L} \mathrm{fed} \mathrm{d}^{-1}\right.$ ) was drilled into the soil near the plants resulted from the pretreated seeds with rhizobia, while those plants resulted from the pretreated seeds with humic acid were sprayed with humic acid (at the concentration of $(10 \mathrm{~g} / 50 \mathrm{~L})$ at the same times of rhizobia application. The plant residues compost was used at the rate of $10 \mathrm{~m}^{3} \mathrm{fed}^{-1}$ combined with 25 or $50 \mathrm{~kg} \mathrm{~N} \mathrm{fed}^{-1}$. Nitrogen fertilizer was applied at the rate of 25 or $50 \mathrm{~kg} \mathrm{~N}$ fed $^{-1}$ in the form of urea $(46 \% \mathrm{~N})$ in three split equal doses after 21,45 and 62 days from sowing.

Table (1): Initial physical and chemical analyses of the experimental soil

\begin{tabular}{|c|c|c|c|c|c|c|c|c|c|}
\hline Location & $\begin{array}{c}\text { Coarse } \\
\text { sand } \\
(\%)\end{array}$ & $\begin{array}{l}\text { Fine } \\
\text { sand } \\
(\%)\end{array}$ & $\begin{array}{l}\text { Silt } \\
(\%)\end{array}$ & $\begin{array}{l}\text { Clay } \\
(\%)\end{array}$ & & Texture & $\begin{array}{l}\text { OM } \\
(\%)\end{array}$ & & $\begin{array}{l}\mathrm{CaCO}_{3} \\
(\%)\end{array}$ \\
\hline \multirow{7}{*}{$\begin{array}{l}\text { Gelbana } \\
\text { village }\end{array}$} & 15.45 & 61.17 & 7.96 & 15.42 & & andy clay & 0.62 & & 8.34 \\
\hline & \multirow{2}{*}{$\begin{array}{c}\mathrm{pH} \\
(1: 2.5) \\
\end{array}$} & \multirow{2}{*}{$\begin{array}{c}\mathrm{EC} \\
\left(\mathrm{dSm}-{ }^{-1}\right)\end{array}$} & \multicolumn{4}{|c|}{ Cations (meq/L) } & \multicolumn{3}{|c|}{ Anions (meq/L) } \\
\hline & & & $\mathbf{C a}^{++}$ & $\mathrm{Mg}^{++}$ & $\mathrm{Na}^{+}$ & $\mathrm{K}^{+}$ & $\mathrm{HCO}_{3}^{-}$ & $\mathrm{Cl}^{-}$ & $\mathrm{SO}^{--}{ }_{4}$ \\
\hline & 8.01 & 5.83 & 4.92 & 9.68 & 44 & 0.75 & 6.28 & 32 & 21.07 \\
\hline & \multicolumn{3}{|c|}{$\begin{array}{l}\text { Macronutrients } \\
\left(\mathrm{mg} \mathrm{kg}^{-1}\right)\end{array}$} & \multicolumn{6}{|c|}{ Micronutrients $\left(\mathrm{mg} \mathrm{kg}^{-1}\right)$} \\
\hline & $\mathbf{N}$ & $\mathbf{P}$ & $\mathrm{K}$ & $\mathrm{Fe}$ & Mn & Zn & \multicolumn{3}{|c|}{$\mathrm{Cu}$} \\
\hline & 37 & 4.36 & 175 & 3.25 & 4.62 & 0.86 & \multicolumn{3}{|c|}{0.53} \\
\hline
\end{tabular}

Table (2): Compost analysis

\begin{tabular}{|l|c|}
\hline \multicolumn{1}{|c|}{ Analysis } & Measurements \\
\hline Moisture content \% & 22.53 \\
pH (1:10, compost : water) & 8.02 \\
EC dS/m(1:10, compost : water) & 2.77 \\
Organic matter \% & 39.81 \\
Organic carbon \% & 23.15 \\
Total N \% & 1.47 \\
Total P \% & 0.32 \\
Total K & 0.40 \\
C/N ratio & $18.9: 1$ \\
DTPA extractable Fe $\left(\mathrm{mg} \mathrm{kg}^{-1}\right)$ & 32.00 \\
DTPA extractable $\mathrm{Mn}\left(\mathrm{mg} \mathrm{kg}^{-1}\right)$ & 71.10 \\
DTPA extractable $\mathrm{Zn}\left(\mathrm{mg} \mathrm{kg}^{-1}\right)$ & 55.0 \\
DTPA extractable Cu $\left(\mathrm{mg} \mathrm{kg}^{-1}\right)$ & 36.0 \\
\hline
\end{tabular}

The experimental design was split plot and comprises 8 treatments in which the types of fertilizer represents the main plot and the rates of nitrogen represent the sub plots as following:

I-Main plots (fertilizer types):

1. Mineral fertilizer

2. biofertilizer

3. humic acid

$4 . \quad$ compost

II-Sub plots (fertilizer rate):

1. $25 \mathrm{~kg} \mathrm{~N}$ fed $^{-1}$

2. $50 \mathrm{~kg} \mathrm{~N} \mathrm{fed}^{-1}$

The experimental plot area was $10 \times 7 \mathrm{~m}$ with three replicates for each treatment. The experiment was started by sowing peanut seeds (Giza 6) at $2^{\text {nd }}$ and $5^{\text {th }}$ May, 2007 and 2008 seasons, respectively. Peanut 
seeds were sown into hills at $50 \mathrm{~cm}$ between ridges and $10 \mathrm{~cm}$ between hills. After 15 days of sowing, plants were thinned out to secure one plant per hill.

All the experimental plots received phosphorus at the rate of $50 \mathrm{~kg}$ $\mathrm{P}_{2} \mathrm{O}_{5}$ applied uniformly before sowing in the form of calcium super phosphate $15 \% \mathrm{P}_{2} \mathrm{O}_{5}$ and potassium at the rate of $50 \mathrm{~kg} \mathrm{~K}_{2} \mathrm{O} \mathrm{fed}-1$ applied in the form of potassium sulphate $48 \% \mathrm{~K}_{2} \mathrm{O}$ one month later after sowing.

At harvest (130 days from sowing), peanut plants were harvested to determine peanut yield (pod yield, seed yield, straw yield and 100-seed weight). Straw and seed samples were taken, oven dried ground and digested according to Thomas et al. (1967) then subjected to the determination of N, P and K content as described by Van Schouwenburg (1968), then the N, P and K uptake by seed and straw was calculated. Protein \% in seeds was calculated by multiplying \% nitrogen by 6.25 (Tripathi et al., 1971). Also seed oil\% was determined according to method described by (A.O.C.S., 1982). Available macronutrients in the soil remained after peanut harvesting was extracted and determined as described by Jackson (1976). Available micronutrients such, i.e., Fe, $\mathrm{Mn}, \mathrm{Zn}$ and $\mathrm{Cu}$ were determined as described by Alpha (1992) using By-Uni Com atomic spectrometer model Solar 969AA atomic absorption spectrophotometer.

All the obtained results were statistically analyzed according Snedecor and Cochran (1980).

\section{Inoculants preparation:}

A salt tolerant Bradyrhizobium sp.isolate (provided by Biofertilizer production Unit, Soils, Water and Environ, Res. Inst., Agric. Res. Center (ARC), Giza, Egypt, was cultured in Yeast Mannitol Broth medium (Vincent, 1970) incubated at $28{ }^{\circ} \mathrm{C}$ for three days on rotary shaker until early log phase to ensure population density of $4 \times 10^{9} \mathrm{cfu} / \mathrm{ml}$ culture. Vermiculite supplemented with $10 \%$ Irish peat was paced into polyethylene bags $(300 \mathrm{~g}$ carrier per bag), then sealed and sterilized with gamma irradiation $\left(5.0 \times 10^{6}\right.$ rads). Bradyrhizobium culture was injected into the carrier to $60 \%$ of the maximum water holding capacity.

\section{RESULTS AND DISSCUTION}

\section{Peanut yield and 100 -seed weight}

The obtained data in Table (3) showed significant increases is peanut straw yield due to the combination of biofertilizer, humic acid or compost with $\mathrm{N}$ fertilizer compared with $\mathrm{N}$ fertilizer application only. On the average of the two $\mathrm{N}$ levels, straw yield increased by $4.3,4.7$ and $6.8 \%$ due to application of biofertilizer, humic acid and compost respectively fertilizer in the first season by $4.4,5.3$ and $7.1 \%$ respectively in the second season. It was also observed that application of compost along with the mineral $\mathrm{N}$ fertilizer recorded the highest straw yield showing significant differences over the biofertilizer or humic acid. Also, slight difference in straw yield between the two $\mathrm{N}$ rates 25 or $50 \mathrm{~kg} \mathrm{~N} / \mathrm{fed}$ were detected when combined with these bio or organic fertilizers showing that $\mathrm{N}$ mineral fertilizer rate could be reduced to a great extent by application of bio or organic fertilizer. 
Table (3): Effect of bio and organic fertilizer application under $\mathbf{N}$ fertilization on peanut yield.

\begin{tabular}{|c|c|c|c|c|c|c|c|c|c|}
\hline \multirow[t]{2}{*}{$\begin{array}{c}\text { Fertilizer } \\
\text { type }\end{array}$} & \multirow{2}{*}{$\begin{array}{c}\text { N-rates } \\
\text { Kg } \\
\text { N/fed }\end{array}$} & \multicolumn{2}{|c|}{$\begin{array}{l}\text { Straw yield } \\
(\mathrm{kg} / \mathrm{fed})\end{array}$} & \multicolumn{2}{|c|}{$\begin{array}{l}\text { Seed yield } \\
(\mathrm{kg} / \mathrm{fed}\end{array}$} & \multicolumn{2}{|c|}{$\begin{array}{l}\text { 100- seeds } \\
\text { weight }(\mathrm{g})\end{array}$} & \multicolumn{2}{|c|}{$\begin{array}{c}\text { Pod yield } \\
\text { (kg/fed) }\end{array}$} \\
\hline & & $\begin{array}{c}1^{\text {st }} \\
\text { season }\end{array}$ & $\begin{array}{c}2^{\text {nd }} \\
\text { season }\end{array}$ & $\begin{array}{c}1^{\text {st }} \\
\text { season }\end{array}$ & $\begin{array}{c}2^{\text {nd }} \\
\text { season }\end{array}$ & $\begin{array}{c}1^{\text {st }} \\
\text { season }\end{array}$ & $\begin{array}{c}2^{\text {nd }} \\
\text { season }\end{array}$ & $\begin{array}{c}1^{\text {st }} \\
\text { season }\end{array}$ & $\begin{array}{c}2^{\text {nd }} \\
\text { season }\end{array}$ \\
\hline \multirow{2}{*}{$\begin{array}{l}\text { Mineral } \\
\text { fertilizer }\end{array}$} & 25 & 1129 & 1138 & 532 & 536 & 61.0 & 62.48 & 821 & 836 \\
\hline & 50 & 1158 & 1154 & 553 & 567 & 64.44 & 64.76 & 852 & 857 \\
\hline \multicolumn{2}{|c|}{ Mean } & 1142 & 1146 & 542 & 551 & 62.57 & 63.62 & 836.5 & 846.5 \\
\hline \multirow{2}{*}{$\begin{array}{c}\text { Bio - } \\
\text { fertilizer }\end{array}$} & 25 & 1188 & 1198 & 677 & 682 & 67.2 & 69.12 & 1016 & 1022 \\
\hline & 50 & 1182 & 1196 & 682 & 692 & 65.12 & 68.36 & 983 & 1002 \\
\hline \multicolumn{2}{|c|}{ Mean } & 1191 & 1197 & 679 & 687 & 66.16 & 68.74 & 999.5 & 1012 \\
\hline \multirow[t]{2}{*}{ Humic } & 25 & 1198 & 1198 & 687 & 678 & 66.73 & 69.42 & 1091 & 1094 \\
\hline & 50 & 1194 & 1216 & 688 & 692 & 68.9 & 72.62 & 1015 & 1030 \\
\hline \multicolumn{2}{|c|}{ Mean } & 1196 & 1207 & 687 & 685 & 67.82 & 71.02 & 1053 & 1062 \\
\hline \multirow[t]{2}{*}{ Compost } & 25 & 1216 & 1223 & 710 & 716 & 78.4 & 79.78 & 1120 & 1128 \\
\hline & 50 & 1225 & 1231 & 715 & 722 & 71.8 & 75.33 & 1132 & 1157 \\
\hline \multicolumn{2}{|c|}{ Mean } & 1220 & 1227 & 712 & 719 & 75.10 & 77.55 & 1126 & 1142.5 \\
\hline \multirow{2}{*}{$\begin{array}{c}\text { Mean of } \mathbf{N} \\
\text { rates }\end{array}$} & 25 & 1183 & 1189 & 651.5 & 653 & 68.33 & 70.20 & 1012 & 1020 \\
\hline & 50 & 1190 & 1199 & 659.5 & 668 & 67.56 & 70.26 & 995.5 & 1012.5 \\
\hline \multirow{3}{*}{\multicolumn{2}{|c|}{$\begin{array}{l}\text { LSD at } 0.05 \\
\text { Fertilizer type(a) } \\
\text { N-rate (b) } \\
\text { a } \times \text { b b }\end{array}$}} & 14.83 & 13.34 & 7.22 & 6.95 & n.s & n.s & 13.18 & 12.93 \\
\hline & & 10.48 & 9.45 & 5.58 & 4.89 & n.s & n.s & 9.32 & 9.15 \\
\hline & & 22.31 & 21.10 & 11.92 & 10.23 & n.s & n.s & 20.12 & 20.93 \\
\hline
\end{tabular}

Meanwhile, the combination of the biofertilizer, humic acid and compost with mineral $\mathrm{N}$ fertilizer gave significant increases in seed yield as shown in Table (3). Seed yield increased by 25.2, 26.7 and $31.3 \%$ over the mineral $\mathrm{N}$ fertilizer alone due to biofertilizer, humic acid and compost respectively in the first season and the corresponding increases in the second season were 24.7, 24.3 and $30.5 \%$. Also, application of compost along with mineral $\mathrm{N}$ fertilizer recorded the seed yield with slight differences between the two $\mathrm{N}$ rates in favour of the high $\mathrm{N}$ rate $(50 \mathrm{~kg} \mathrm{~N} / \mathrm{fed})$

In conclusion, the highest straw and seed yields were mostly associated with joint application of biofertilizer, humic acid or compost and mineral $\mathrm{N}$ fertilizer at two rates in favour of compost with difference between the two $\mathrm{N}$ rates. The positive effect of compost could be attributed to that the effect of organic manure is mainly chemical as well as physical due to the formation of organic and inorganic acids as a result of organic manure decomposition beside improving newly reclaimed soil structure. Also, the behaviour of the biofertilizer may be explained on the basis of bacterial effects on nutrient availability, vital enzyme, hormones stimulating for plant growth and the synergistic effect of the microorganisms. There are also many reports of humic acid role in promoting plant biomass, stimulation of seed, straw and flowering growth and even direct effect on crop productivity and increases in crop yields. The obtained results are in agreement with those obtained by Shaban et al. (2008).

Although the joint application of bio-and organic fertilizers and mineral $\mathrm{N}$ fertilizer induced increases in 100-seed weight during both growing seasons, these increases did not reach the significant level. 
Meanwhile, pod yield of peanut under the different applied treatments showed the same trends of both straw and seed yields as shown in Table (3), since application of biofertilization induced significant increase in pod yield relative to $\mathrm{N}$ fertilization only by $19.5,25.9$ and $34.7 \%$ respectively in the first season and by $19.6,25.5$ and $35.0 \%$ respectively in the second season.

Generally, the effectiveness of the applied treatments on peanut yield is in favour of compost followed by humic acid then biofertilizer while mineral $\mathrm{N}$ fertilization recorded the least peanut yield.

\section{Seed protein and oil contents:}

The results in Table (4) revealed that the bio-organic fertilization under $\mathrm{N}$ fertilization caused different increases in seed protein content relative to mineral $\mathrm{N}$ fertilization alone, and increases were statistically significant in the second season only in favour of compost. On the other hand, seed oil content was more affected by the applied treatments than seed protein content. In the first season, seed oil content increased significantly from $33 \%$ for mineral $\mathrm{N}$ fertilization only to $38 \%$ for biofertilization, $40 \%$ for humic acid and $42 \%$ for compost and the same values were nearly obtained in the second season, such results assured the findings by Shaban et al. (2008).

Table (4): Effect of bio and organic fertilizer application under $\mathbf{N}$ fertilization on peanut seed protein and oil contents during two season

\begin{tabular}{|c|c|c|c|c|c|}
\hline \multirow{2}{*}{$\begin{array}{c}\text { Fertilizer } \\
\text { type }\end{array}$} & \multirow{2}{*}{$\begin{array}{l}\text { N-rates } \\
\mathrm{Kg} \mathrm{N} / \text { fed }\end{array}$} & \multicolumn{2}{|c|}{ Protein (\%) } & \multicolumn{2}{|c|}{ Oil (\%) } \\
\hline & & $\begin{array}{c}1^{\text {st }} \\
\text { season }\end{array}$ & $2^{\text {nd }}$ season & $\begin{array}{c}1^{\text {st }} \\
\text { season }\end{array}$ & $2^{\text {nd }}$ season \\
\hline \multirow[t]{2}{*}{ Mineral fertilizer } & 25 & 11.50 & 11.50 & 32 & 30 \\
\hline & 50 & 12.00 & 12.69 & 34 & 37 \\
\hline \multicolumn{2}{|c|}{ Mean } & 11.75 & 12.09 & 33 & 33.5 \\
\hline \multirow[t]{2}{*}{ Bio -fertilizer } & 25 & 1313 & 13.19 & 39 & 39 \\
\hline & 50 & 13.25 & 13.25 & 37 & 37 \\
\hline \multicolumn{2}{|c|}{ Mean } & 13.19 & 13.22 & 38 & 38 \\
\hline \multirow[t]{2}{*}{ Humic } & 25 & 1313 & 13.19 & 39 & 38 \\
\hline & 50 & 13.31 & 13.44 & 42 & 41 \\
\hline \multicolumn{2}{|c|}{ Mean } & 13.22 & 13.32 & 40.5 & 39.5 \\
\hline \multirow[t]{2}{*}{ Compost } & 25 & 13.38 & 13.69 & 41 & 40 \\
\hline & 50 & 13.56 & 13.81 & 44 & 44 \\
\hline \multicolumn{2}{|c|}{ Mean } & 13.47 & 13.75 & 42.5 & 42 \\
\hline \multirow[t]{2}{*}{ Mean of $\mathrm{N}$ rates } & 25 & 12.72 & 12.89 & 38.0 & 37.0 \\
\hline & 50 & 13.03 & 13.30 & 39.0 & 40.0 \\
\hline \multicolumn{2}{|l|}{$\begin{array}{l}\text { LSD at } 0.05 \\
\text { Fertilizer type(a) } \\
\text { N-rate (b) } \\
\text { a x b }\end{array}$} & $\begin{array}{l}\text { n.s } \\
0.21 \\
\text { n.s }\end{array}$ & $\begin{array}{c}0.28 \\
0.19 \\
\text { n.s }\end{array}$ & $\begin{array}{l}0.87 \\
0.62 \\
1.30\end{array}$ & $\begin{array}{l}1.22 \\
0.86 \\
2.01\end{array}$ \\
\hline
\end{tabular}

\section{$\mathrm{N}, \mathrm{P}$ and $\mathrm{K}$ uptake:}

Joint application of biofertilizer, humic acid or compost and mineral $\mathrm{N}$ fertilization gave significant increases in $\mathrm{N}, \mathrm{P}$ and $\mathrm{K}$ uptake by both straw and seed in favour of compost which recorded the highest N, P and $\mathrm{k}$ uptake relative to $\mathrm{N}$ fertilization alone during the two growing seasons (Tables 5 and 6). On average of the two $\mathrm{N}$ rates, the highest $\mathrm{N}, \mathrm{P}$ and $\mathrm{K}$ uptake by 
straw or seeds was achieved by compost application followed by humic acid then biofertilizer, while mineral $\mathrm{N}$ fertilization only gave the lowest $\mathrm{N}, \mathrm{P}$ and $\mathrm{K}$ amounts taken up by straw or seeds of peanut grown in newly reclaimed saline soil.

Table (5): Effect of bio and organic fertilizer application under $\mathrm{N}$ fertilization on $\mathrm{N}, \mathrm{P}$ and $\mathrm{K}$ uptake by peanut straw during two seasons.

\begin{tabular}{|c|c|c|c|c|c|c|c|}
\hline \multirow{2}{*}{$\begin{array}{c}\text { Fertilizer } \\
\text { type }\end{array}$} & \multirow{2}{*}{$\begin{array}{l}\text { N-rates } \\
\mathrm{Kg} \mathrm{N} / \text { fed }\end{array}$} & \multicolumn{2}{|c|}{ N-uptake (kg/fed) } & \multicolumn{2}{|c|}{ P-uptake (kg/fed) } & \multicolumn{2}{|c|}{ K-uptake (kg/fed) } \\
\hline & & $\begin{array}{c}1^{\text {st }} \\
\text { season }\end{array}$ & $\begin{array}{c}2^{\text {nd }} \\
\text { season }\end{array}$ & $\begin{array}{c}1^{\text {st }} \\
\text { season }\end{array}$ & $\begin{array}{c}2^{\text {nd }} \\
\text { season }\end{array}$ & $\begin{array}{c}1^{\text {st }} \\
\text { season }\end{array}$ & $\begin{array}{c}2^{\text {nd }} \\
\text { season }\end{array}$ \\
\hline \multirow{2}{*}{$\begin{array}{l}\text { Mineral } \\
\text { fertilizer }\end{array}$} & 25 & 40.02 & 40.71 & 2.82 & 3.19 & 31.27 & 32.09 \\
\hline & 50 & 43.48 & 43.99 & 3.71 & 4.04 & 33.46 & 33.92 \\
\hline \multicolumn{2}{|c|}{ Mean } & 41.75 & 42.35 & 3.26 & 3.62 & 32.36 & 32.77 \\
\hline \multirow[t]{2}{*}{ Bio -fertilizer } & 25 & 45.13 & 46.03 & 4.16 & 4.55 & 33.38 & 34.02 \\
\hline & 50 & 43.60 & 44.48 & 3.9 & 4.31 & 33.10 & 34.21 \\
\hline \multicolumn{2}{|c|}{ Mean } & 44.36 & 45.25 & 4.03 & 4.43 & 33.24 & 34.12 \\
\hline \multirow[t]{2}{*}{ Humic } & 25 & 45.26 & 45.80 & 4.55 & 4.79 & 34.26 & 34.50 \\
\hline & 50 & 45.81 & 46.78 & 4.81 & 5.47 & 34.63 & 35.63 \\
\hline \multicolumn{2}{|c|}{ Mean } & 45.53 & 46.29 & 4.68 & 5.13 & 34.44 & 35.07 \\
\hline \multirow[t]{2}{*}{ Compost } & 25 & 46.57 & 47.02 & 5.35 & 5.26 & 36.72 & 36.93 \\
\hline & 50 & 48.07 & 47.82 & 4.90 & 5.79 & 36.75 & 37.55 \\
\hline \multicolumn{2}{|c|}{ Mean } & 47.32 & 47.42 & 5.13 & 5.53 & 36.73 & 37.05 \\
\hline \multirow{2}{*}{$\begin{array}{l}\text { Mean of } \mathbf{N} \\
\text { rates }\end{array}$} & 25 & 44.25 & 44.89 & 4.22 & 4.45 & 33.91 & 34.38 \\
\hline & 50 & 45.24 & 45.77 & 4.33 & 4.90 & 34.48 & 35.33 \\
\hline \multirow{2}{*}{\multicolumn{2}{|c|}{ LSD at 0.05}} & & & & & & \\
\hline & & 0.665 & 0.4009 & 0.170 & 0.127 & 0.521 & 0.432 \\
\hline \multicolumn{2}{|c|}{$\begin{array}{c}\text { Fertilizer type(a) } \\
\text { N-rate (b) }\end{array}$} & 0.471 & 0.2830 & 0.120 & 0.090 & 0.360 & 0.366 \\
\hline \multicolumn{2}{|c|}{$\mathbf{a} \times \mathbf{b}$} & 1.520 & 0.532 & n.s & 0.201 & 0.744 & 0.721 \\
\hline
\end{tabular}

Table (6): Effect of bio and organic fertilizer application under $\mathbf{N}$ fertilization on $\mathrm{N}, \mathrm{P}$ and $\mathrm{K}$ uptake by peanut seeds during two seasons.

\begin{tabular}{|c|c|c|c|c|c|c|c|}
\hline \multirow{2}{*}{$\begin{array}{c}\text { Fertilizer } \\
\text { type }\end{array}$} & \multirow{2}{*}{$\begin{array}{l}\text { N-rates } \\
\text { Kg N/fed }\end{array}$} & \multicolumn{2}{|c|}{ N-uptake (kg/fed) } & \multicolumn{2}{|c|}{ P-uptake (kg/fed) } & \multicolumn{2}{|c|}{ K-uptake (kg/fed) } \\
\hline & & $\begin{array}{c}1^{\text {st }} \\
\text { season }\end{array}$ & $2^{\text {nd }}$ season & $\begin{array}{c}1^{\text {st }} \\
\text { season }\end{array}$ & $2^{\text {nd }}$ season & $\begin{array}{c}1^{\text {st }} \\
\text { season }\end{array}$ & $2^{\text {nd }}$ season \\
\hline \multirow{2}{*}{$\begin{array}{l}\text { Mineral } \\
\text { fertilizer }\end{array}$} & 25 & 9.99 & 10.12 & 2.07 & 2.36 & 6.17 & 6.38 \\
\hline & 50 & 10.64 & 11.35 & 2.49 & 2.84 & 6.96 & 7.37 \\
\hline \multicolumn{2}{|l|}{$\begin{array}{r}\text { Mean } \\
\end{array}$} & 10.32 & 10.74 & 2.28 & 2.60 & 6.56 & 6.87 \\
\hline \multirow[t]{2}{*}{ Bio -fertilizer } & 25 & 14.54 & 14.70 & 3.25 & 3.68 & 8.73 & 9.21 \\
\hline & 50 & 14.58 & 14.64 & 3.41 & 3.94 & 9.07 & 9.62 \\
\hline \multicolumn{2}{|c|}{ Mean } & 14.56 & 14.67 & 3.33 & 3.81 & 8.90 & 9.42 \\
\hline \multirow[t]{2}{*}{ Humic } & 25 & 14.41 & 14.60 & 3.84 & 4.00 & 9.62 & 9.49 \\
\hline & 50 & 14.79 & 15.03 & 3.85 & 4.15 & 9.63 & 9.96 \\
\hline \multicolumn{2}{|c|}{ Mean } & 14.60 & 14.82 & 3.85 & 4.07 & 9.63 & 9.73 \\
\hline \multirow[t]{2}{*}{ Compost } & 25 & 15.06 & 15.53 & 4.47 & 4.58 & 9.87 & 10.23 \\
\hline & 50 & 15.51 & 15.89 & 4.36 & 4.54 & 10.08 & 10.54 \\
\hline \multicolumn{2}{|c|}{ Mean } & 15.28 & 15.71 & 4.12 & 4.56 & 9.98 & 10.39 \\
\hline \multirow{2}{*}{$\begin{array}{l}\text { Mean of } \mathrm{N} \\
\text { rates }\end{array}$} & 25 & 13.50 & 13.74 & 3.41 & 3.65 & 8.60 & 8.83 \\
\hline & 50 & 13.87 & 14.24 & 3.53 & 3.87 & 8.93 & 9.37 \\
\hline \multicolumn{2}{|c|}{\begin{tabular}{|l} 
LSD at 0.05 \\
Fertilizer type(a) \\
N-rate (b) \\
a x b
\end{tabular}} & $\begin{array}{c}0.538 \\
0.168 \\
\text { n.s }\end{array}$ & $\begin{array}{c}0.612 \\
0.171 \\
\text { n.s }\end{array}$ & $\begin{array}{l}0.109 \\
0.077 \\
0.121\end{array}$ & $\begin{array}{l}0.069 \\
0.049 \\
0.110\end{array}$ & $\begin{array}{l}0.145 \\
0.102 \\
\text { n.s }\end{array}$ & $\begin{array}{l}0.220 \\
0.159 \\
0.311\end{array}$ \\
\hline
\end{tabular}


It was also noticed that the inoculation with biofertilizer under the low $\mathrm{N}$ rate $(25 \mathrm{~kg} \mathrm{~N} / \mathrm{fed}$ ) caused higher $\mathrm{N}$ uptake by straw than under $50 \mathrm{~kg} \mathrm{~N} / \mathrm{fed}$ due to the $\mathrm{N}$ fixed by rhizobia confirming $\mathrm{N}$ reservation by rhizobia species. Also, compost decomposition resulted in free organic or inorganic acids which improve the nutrient availability and hence nutrient uptake by plant organs. These results are in parallel with those recorded by El-Fayoumy and Ramadan (2002) with peanut and Shaban et al. (2008) with maize. They reported that the inoculation with the halo tolerant bacterial strains enabled both maize and peanut to with stand the adverse effect of the saline soil condition. However, the nutrient N, P and K uptake by straw and seeds under compost application surpassed the amounts taken up under the other applied treatments as shown in Tables (5) and (6).

Micronutrient contents:

The straw and seed contents of micronutrients, i.e. $\mathrm{Fe}, \mathrm{Mn}, \mathrm{Zn}$ and $\mathrm{Cu}$ as affected by the application of biofertilizer, humic acid or compost under two $\mathrm{N}$ rates are presented in Table (7).

Table (7): Micronutrients concentration $\left(\mathrm{mgkg}^{-1}\right)$ in peanut straw and seed as affected by bio, organic and nitrogen fertilization during two seasons (2007 and 2008)

\begin{tabular}{|c|c|c|c|c|c|c|c|c|c|c|c|c|c|c|c|}
\hline \multirow[t]{4}{*}{ Treatments } & \multirow{4}{*}{$\begin{array}{c}\mathrm{N}- \\
\text { rates } \\
\mathrm{Kg} \\
\mathrm{N} / \mathrm{fed}\end{array}$} & \multicolumn{4}{|c|}{$\mathrm{Fe}$} & \multicolumn{4}{|c|}{ Mn } & \multicolumn{4}{|c|}{$\mathrm{Zn}$} & \multicolumn{2}{|c|}{$\mathrm{Cu}$} \\
\hline & & \multicolumn{2}{|c|}{ Straw } & \multicolumn{2}{|c|}{ Seed } & \multicolumn{2}{|c|}{ Straw } & \multicolumn{2}{|c|}{ Seed } & \multicolumn{2}{|c|}{ Straw } & \multicolumn{2}{|c|}{ Seed } & Straw & \multirow{3}{*}{\begin{tabular}{|c|} 
Seed \\
$2007 \mid 2008$
\end{tabular}} \\
\hline & & 2007 & 2008 & 2007 & 207008 & 2007 & 2008 & 2007 & 2008 & 2007 & 2008 & 2007 & 2008 & 20072008 & \\
\hline & & & & & & & & & & & & & & & \\
\hline \multirow{3}{*}{$\begin{array}{l}\text { Mineral } \\
\text { fertilizer }\end{array}$} & 25 & 137 & 142 & 67 & 75 & 52 & 56 & 27 & 31 & 40 & 44 & 15 & 17 & \begin{tabular}{|l|l|}
7.63 & 7.69 \\
\end{tabular} & 0.971 .03 \\
\hline & 50 & 145 & 150 & 70 & 72 & 57 & 61 & 31 & 35 & 45 & 50 & 18 & 20 & \begin{tabular}{|l|l|}
8.48 & 8.5 \\
\end{tabular} & 1.051 .10 \\
\hline & Mean & 141 & 146 & 68 & 72 & 54 & 58 & 29 & 33 & 42 & 47 & 16 & 18 & 8.058 .11 & \begin{tabular}{|l|l|}
1.01 & 1.06 \\
\end{tabular} \\
\hline \multirow{3}{*}{$\begin{array}{c}\text { Bio - } \\
\text { fertilizer }\end{array}$} & \begin{tabular}{|l|}
25 \\
\end{tabular} & 162 & 167 & 75 & 78 & 66 & 68 & 40 & 46 & 51 & 56 & 23 & 27 & \begin{tabular}{|l|l|}
7.23 & 7.24 \\
\end{tabular} & \begin{tabular}{|l|l|}
1.04 & 1.08 \\
\end{tabular} \\
\hline & 50 & 178 & 180 & 77 & 80 & 61 & 63 & 37 & 39 & 58 & 62 & 22 & 25 & \begin{tabular}{|l|l|}
8.79 & 8.83 \\
\end{tabular} & \begin{tabular}{|l|l|}
1.13 & 1.17 \\
\end{tabular} \\
\hline & Mean & 170 & 173 & 76 & 79 & 63 & 65 & 38 & 42 & 54 & 59 & 22 & 26 & \begin{tabular}{|l|l|}
8.01 & 8.03 \\
\end{tabular} & \begin{tabular}{|l|l|}
1.08 & 1.12 \\
\end{tabular} \\
\hline \multirow[t]{3}{*}{ Humic } & \begin{tabular}{|l|}
25 \\
\end{tabular} & 174 & 178 & 74 & 77 & 64 & 66 & 37 & 40 & 58 & 60 & 23 & 26 & 8.968 .99 & 1.121 .15 \\
\hline & 50 & 181 & 186 & 77 & 81 & 68 & 70 & 39 & 43 & 61 & 63 & 25 & 29 & \begin{tabular}{|c|c|}
9.10 & 9.15 \\
\end{tabular} & 1.161 .20 \\
\hline & Mean & 177 & 182 & 75 & 79 & 66 & 68 & 38 & 41 & 59 & 61 & 24 & 27 & 9.039 .07 & 1.14 \\
\hline \multirow[t]{3}{*}{ Compost } & \begin{tabular}{|l|}
25 \\
\end{tabular} & 183 & 185 & 78 & 80 & 67 & 69 & 38 & 41 & 60 & 63 & 24 & 28 & 9.159 .17 & 1.161 .19 \\
\hline & 50 & 187 & 191 & 81 & 84 & 71 & 74 & 40 & 44 & 66 & 69 & 26 & 30 & 9.249 .27 & 1.181 .23 \\
\hline & Mean & 185 & 188 & 79 & 82 & 69 & 71 & 39 & 42 & 63 & 66 & 25 & 29 & $8.24 \mid 9.22$ & \begin{tabular}{|l|l|}
1.17 & 1.21 \\
\end{tabular} \\
\hline \multirow{2}{*}{$\begin{array}{l}\text { Mean of } \mathrm{N} \\
\text { rates }\end{array}$} & \begin{tabular}{|l|}
25 \\
\end{tabular} & 164 & 168 & 73 & 76 & 62 & 65 & 35 & 39 & 52 & 56 & 21 & 24 & 8.908 .27 & 1.071 .11 \\
\hline & 50 & 173 & 177 & 76 & 80 & 64 & 67 & 37 & 40 & 57 & 61 & 23 & 26 & 8.908 .95 & 1.131 .17 \\
\hline
\end{tabular}

The results also revealed marked increases in both straw and seed contents of the above mentioned micronutrients due to application of biofertilizer, humic acid or compost when compared to mineral $\mathrm{N}$ fertilization alone and compost application gave the highest concentrations of the studied micronutrients. It was also noticed that the increases in micronutrient contents were more pronounced in straw than in seeds. The obtained results also showed both straw and seed contents of $\mathrm{Cu}$ were less affected by the applied treatments than other micronutrients. Moreover, application of biofertilizer, humic acid or compost along with $50 \mathrm{~kg} \mathrm{~N} / \mathrm{fed}$ showed higher straw and seed contents of the studied micronutrients than those under $25 \mathrm{~kg}$ $\mathrm{n} / \mathrm{fed}$ except $\mathrm{Mn}$ content in both straw and seeds which was higher by biofertilizer application combined with the lower $\mathrm{N}$ rate (Table 7 ). The 
increases in both straw and seed contents of the studied micronutrients as a result of the application of bio-organic fertilizers could be attributed to the acidic effect of the bio-organic fertilizer which led to lowering soil $\mathrm{pH}$ and in turn increase the micronutrients availability in soil and hence micronutrient uptake by peanut plants. These results agreed with those obtained by Nasef et al. (2006), Shaban et al. (2008) and Bama and Selvakuman (2001).

Soil available nutrients after peanut harvest:

Available macronutrients, $\mathrm{N}, \mathrm{P}$ and $\mathrm{K}$ :

Data in Table (8) showed the amounts of the available N, P and K remained in the soil after peanut harvest as affected by bio or organic fertilization under mineral $\mathrm{N}$ fertilization for two seasons. The results revealed that soil fertility status in terms of available N, P and K contents was greatly improved by application of bio or organic fertilizers. The soil treated with bio or organic fertilizers under $\mathrm{N}$ fertilization gave pronounced increases in $\mathrm{N}, \mathrm{P}$ and $\mathrm{K}$ amounts compared to $\mathrm{N}$ fertilization alone during the two growing seasons with slight differences among the bio-organic fertilizers. The treatments received compost along with $50 \mathrm{~kg} \mathrm{~N} / \mathrm{fed}$ recorded the highest soil available $\mathrm{N}, \mathrm{P}$ or $\mathrm{K}$ after harvest. For instance, the available soil $\mathrm{N}$ content was 74 and $77 \mathrm{mg} \mathrm{kg}^{-1}$ for compost in the first and second season respectively, while the corresponding $\mathrm{N}$ contents were 71 and $74 \mathrm{mg} \mathrm{kg}^{-1}$ for humic, 70 and $74 \mathrm{mg} \mathrm{kg}^{-1}$ for biofertilizer, while mineral $\mathrm{n}$ fertilization recorded the least contents (52 and $55 \mathrm{mg} \mathrm{kg}^{-1}$ ).

Table (8): Available Macro-and Micronutrients contents in soil after peanut harvesting as affected by bio, organic and nitrogen fertilization during two seasons (2007 and 2008)

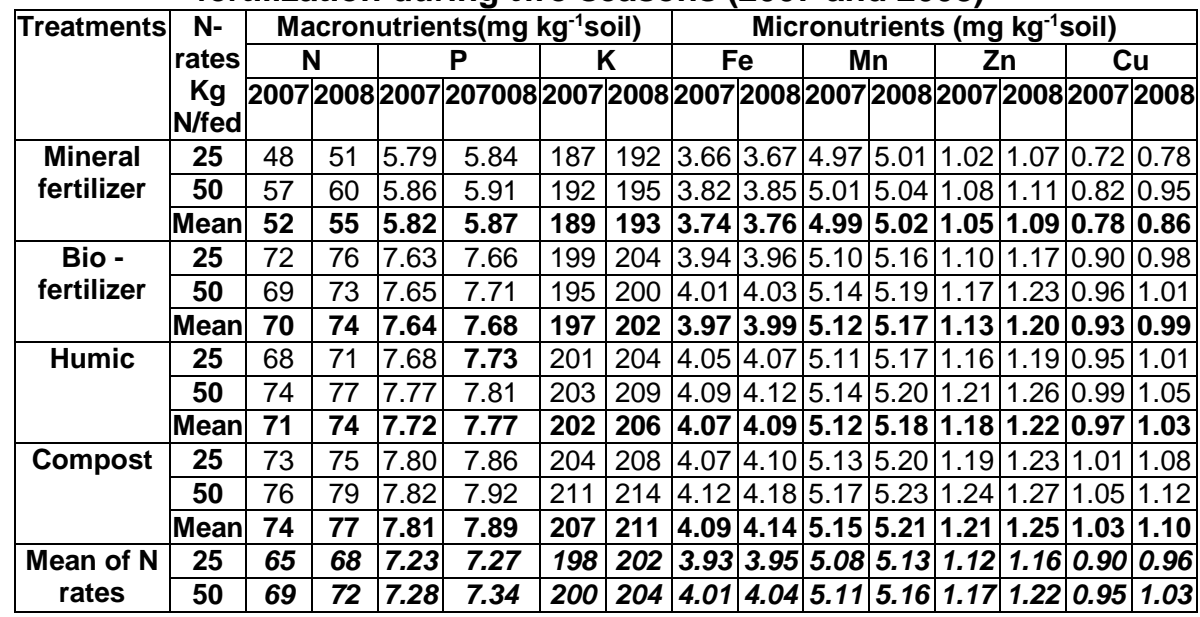

On average of the two seasons, the available $P$ increased from about $5.85 \mathrm{mg} \mathrm{kg}^{-1}$ for mineral $\mathrm{N}$ fertilizer to about $7.66 \mathrm{mg} \mathrm{kg}^{-1}$ for biofertilization, $7.74 \mathrm{mg} \mathrm{kg}^{-1}$ for humic to $7.85 \mathrm{mg} \mathrm{kg}^{-1}$ for compost. Also, the available $\mathrm{K}$ content (on average of the two seasons) increased from $191 \mathrm{mg} \mathrm{kg}^{-1}$ for $\mathrm{N}$ fertilization to 199, 204 and $209 \mathrm{mg} \mathrm{kg}^{-1}$ for biofertilizer, humic and compost application respectively. 
It could be mentioned that the available $\mathrm{N}, \mathrm{P}$ and $\mathrm{K}$ levels increased from the low level under mineral fertilization to the medium levels under bioorganic fertilization. In this respect, Bhattacharyya et al. (2008) stated that the application of FYM resulted in increases in available $\mathrm{N}, \mathrm{P}$ and $\mathrm{K}$ in the soils, as FYM increased soil cation exchange capacity. Also, Wang et al. (1995) reported that the addition of humic acid to soil combined with $\mathrm{P}$ fertilizer increased significantly the amount of water soluble phosphate.

\section{Available micronutrients; $\mathrm{Fe}, \mathrm{Mn}, \mathrm{Zn}$ and $\mathrm{Cu}$ :}

Data presented in Table (8) revealed less increase in soil available micronutrients, $\mathrm{Fe}, \mathrm{Mn}, \mathrm{Zn}$ and $\mathrm{Cu}$ due to the application of bio or organic fertilizers in both season than those obtained with the above mentioned macronutrients. On average of the two seasons, $\mathrm{Fe}$ content increased from $3.75 \mathrm{mg} \mathrm{kg}^{-1}$ with mineral $\mathrm{n}$ fertilizer to $3.98,4.08$ and $4.12 \mathrm{mg} \mathrm{kg}^{-1}$ with biofertilizer, humic and compost respectively. The corresponding values for $\mathrm{Mn}$ were $5.00,5.14,5.15$ and $5.18 \mathrm{mg} \mathrm{kg}^{-1}$, for $\mathrm{Zn}, 1.07,1.16,1.20$ and 1.23 and for $\mathrm{Cu} 0.87,0.96,1.00$ and $1.06 \mathrm{mg} \mathrm{kg}^{-1}$ for mineral $\mathrm{N}$, biofertilizer, humic and compost, respectively.

This is more related to the residual organic compounds and biochemical and chemical changes, which led to release more available micronutrients. It is worthy to mentioned that the contents of the studied available micronutrients; $\mathrm{Fe}, \mathrm{Mn}, \mathrm{Zn}$ and $\mathrm{Cu}$, generally lay within the sufficient limits or in the critical limits according to FAO (1992). These results are in agreement with those obtained by Ashmaye et al. (2008) who found that applying soil amendments caused increases in the soil available micronutrient concentration of $\mathrm{Fe}, \mathrm{Mn}, \mathrm{Zn}$ and $\mathrm{Cu}$ for maize. The results also agreed with those obtained by Abas (2003) and Shaban et al. (2008).

From the above results of the present study, it could be concluded that application of biofertilizer, humic acid or compost jointly with mineral $\mathrm{N}$ fertilization at the lower level $(25 \mathrm{~kg} \mathrm{~N} / \mathrm{fed})$ could improve soil fertility status and hence the growth and economic yield of peanut under newly reclaimed saline soils. The beneficial effects of the applied materials could be categorized in descending order of compost> humic acid> biofertilizer> mineral $\mathrm{N}$.

This experiment should be repeated at different sites with soil salinity problems to establish this idea to reach the degree of recommendation.

\section{REFERENCES}

Abas Faten, A. (2003). Effect of some soil conditioners on fertility and productivity of sandy soil. Thesis, M.Sc. Faculty of Agric. Moshtohor, Zagazig Universty, Benha Branch.

American Public Health Association (APHA) (1992). Standard Methods for the Examination of Water and Wastewater (18 ${ }^{\text {th }}$ ed.). American Public Health Association (APHA) American Water Work Association (AWWA) and Water Environmental Federation, Washington, USA.

A. O. C. S. (1982). Official and Tentative Methods of American Oil Chemists Society, 35 East Wolker Drive, Chicago, ILLinois, USA. 
Aswhmaye, S. H.; Kh. A. Shaban and M. G. Abd El-Kader (2008). Effect of mineral nitrogen, sulphure, organic and bio-fertilization on maize productivity in saline soil of sahl El-Tina. Minufiya. J. Agric. Res., 33(1):195-209.

Bama, K. S. and G. Selvakumari (2001). Effect of humic acid on growth yield and nutrition of amaranthus. South Indian Hort., 49:155-156.

Bhattacharyya, R. S.; V. P. Kundue and H. S. Gupta (2008). Sustainability under combined application of mineral and organic fertilizers in a rainfed soybean-wheat system of the Indian. Himalayas. Europe. J. Agronomy. 28:33-46.

Black, C. A. (1965). In " Methods of soil Analysis" Part II. Amer. Soc. Agron. Inc., Publisher Madison, Wisconson, USA.

Brunner, P. H. and H. R. Wasmer (1978). Methods of analysis of sewage sludge solid wastes and compost W.H.O. International Reference Center for Wastes Disposal (H-8600) Dulendrof, Germany.

El-Fayoumy, M. E. and H. M. Ramadan (2002). Effect of bio-organic manures on sandy soils amelioration and peanut productivity under sprinkler irrigation system. Egypt. J. Soil Sci., 42(3):383-415.

El-Ghozoli, M. A. (1998). Studies on some organ8ic residues enriched with some macr and micronutrients. Ph.D. Thesis, FAO, Agric. Moshtohor, Banha Branch, Zagazig Univ. Egypt.

El-Sedfy, O. F., A. M. M. Biomy and A. A. Badawy (2005). Response of maize to Bio, organic and nitrogen fertilization in sandy soil. Egypt. J. Appl. Sci., 20(11):269-284.

FAO, (1992). " Waste water treatment and use in agriculture. FAO Soil Bull. No.47, Rome.

Genaidy, S. A. and M. H. Hegazy (1991). Effect of gypsum, organic manure and zinc sulfare application to rice saline sodic soils. J. Agric. Res. Mansoura Univ., 16(2):447-457.

Jackson, M.L.(1976). Soil Chemical Analysis. Prentic-Hall Ins., Engle Wood Cliffs, U.S.A.

Nasef, M. A.; N. M. Badran and Amal, F. A. (2006). Response of peanut to foliar spray with boron and/or Rhizobium inoculation. Journal of Applied Sciences Research. 2 (12):1330-1337.

Page A. L., R. H. Miller and D. R. Keeney (1982).Methods of soil analysis Part 2. Chemical and microbiological properties. Second Edition. Amer Soc. Agron .Madison, Wisconsin, USA .

Rajinder, S. A. and S. Mandeep (2007). Effects of organic manures and fertilizers on organic matter and nutrients status of the soil. Journal of Agronomy and Soil Science. 53 (5):519-528.

Rashid, A. and J. Ryan (2004). Micronutrients constraints to crop production in soils with Mediterranean-type characteristics, a review. Journal of Plant Nutrition. Marcel Dekker, Inc., Monticello, USA: 27(6):959-975.

Shaban, Kh. A.; A. M. Helmy and A. H. Abd El-Rhman (2008). Nutrients uptake and yield quality of soy bean as affected by bio and organic nitrogen fertilizers. Zagazig, J. Agric. Res., 35(2):343-362.

Snderecor, G.W. and G.W. Cochran (1980). Statistical Methods $7^{\text {th }}$ Ed The lowa State, Univ., Press lowa, Ames. USA. 
Thomas, R. L.; R. W. Shearel and Z. R. Mayer (1967). Comparison of conventional and automated procedures for nitrogen, phosphorus and potassium analyses of plant material using single digestion. Agron. J., 59:240.

Tripathi, R. D.; G. P. Srivastava; M. S. Misra and S. C. pandy (1971). Protein evaluation to some legume varieties. The Allaqh Abad Farmer J., 16: 282-290.

Van Schouwenburg, J. Ch. (1968). International Report of Soil and Plant Analysis. Lab. Of Soil and Fertilizer Agric., Univ. of Wageningen, The Netherlands.

Vincent, J. M. (1970). A manual for practical study of root-nodule bacteria IBP Handbook, No.15, Blackwell Sci., Pub., Ltd., Oxford and Edinburgh, UK.

Wang, K. I.; Z. Q. Wang and S. G. Li. (1995). The effect of humic acids on the availability of phosphorus fertilizers in alkaline soils. Soil and Management Journal. 11(2):99-102.

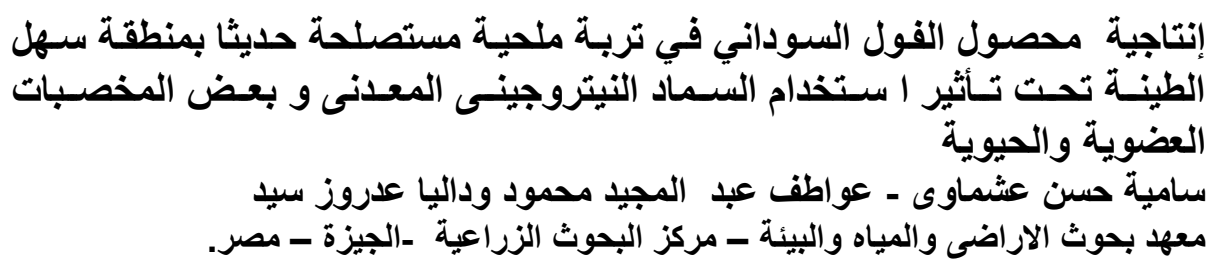

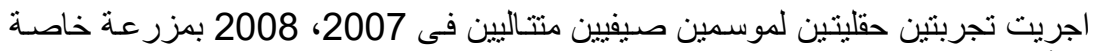

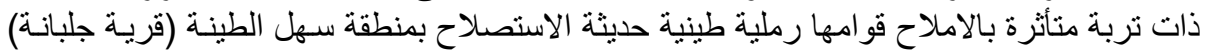

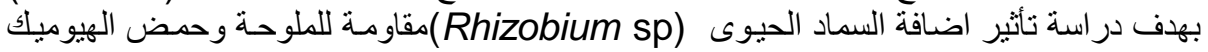

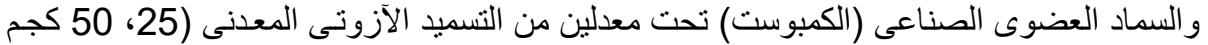

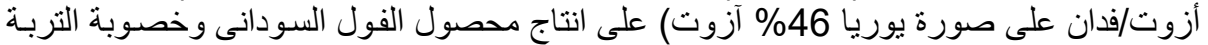

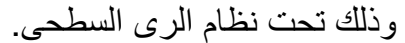

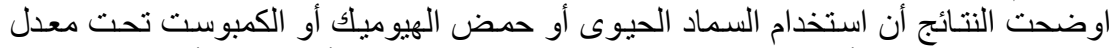

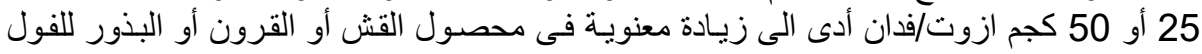

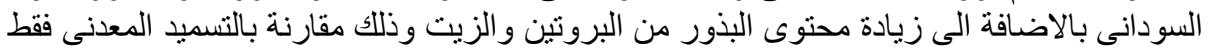

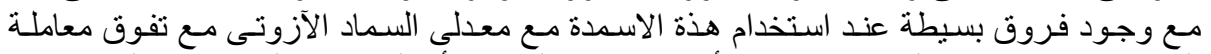

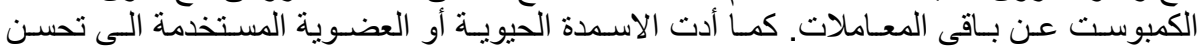

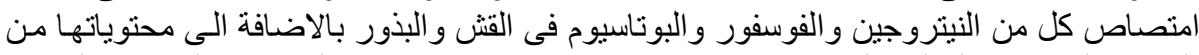

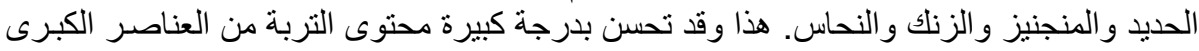

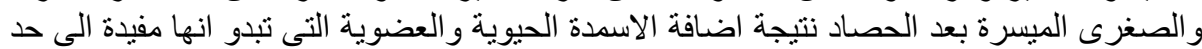

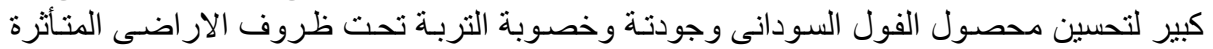

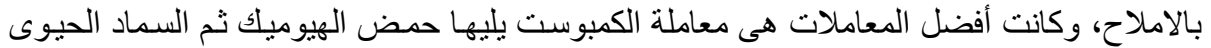
وذلك تحت المعدل المنخفض من التسميد الآزوتى. 